\title{
夢を追い続けて一生物有機化学からアルツハイマー病へ一
}

\author{
中山 仁 \\ Seeking “Etwas Neues”- From Bioorganic Chemistry to Alzheimer's Disease- \\ Hitoshi NAKAYAMA \\ Graduate School of Medical and Pharmaceutical Sciences, Kumamoto University, \\ 5-1 Ohe-Honmachi, Kumamoto City 862-0973, Japan
}

(Receiced May 13, 2008)

\begin{abstract}
Introduction to bioorganic chemistry by Prof. Kanaoka at the entrance of my research works affects greatly throughout the life afterward. Chemical modification studies of enzyme proteins taught me quality of chemical reactions. For example, triethyloxonium fluoroborate $\left(\mathrm{Et}_{3} \mathrm{O}^{+} \mathrm{BF}_{4}^{-}\right)$, a Meerwein reagent, selectively reacted with a particular carboxyl group (Asp-177) in the substrate binding site of trypsin, even though the reaction was performed in aqueous solution. A series of ion channel studies intoxicate me how exciting the science works are. Purification of sodium channel protein from electric eels initiated the collaboration work to reveal total primary structure of the molecule, as an inaugurating work of ion channel molecules. Photoaffinity labeling proved to be an efficient method to elucidate ligand binding sites, such as TTX binding site within the sodium channel and the sites for calcium anatagonists in L-type calcium channels. Encounter with CD36 molecule expands our works to more pathobiochemical field. We revealed CD36, a class $B$ scavenger receptor, is related to development of atherosclerosis by phagocytosis of ox-LDL in macrophages and even matured adipocytes. In microglia, however, CD36 plays clearance role of oligomeric $\beta$-amyloid peptides in IL-4 activated type-2 microglia, suggesting the activation of type-2 microglia may be useful for developing a new method to treat or prevent from Alzheimer's disease.
\end{abstract}

Key words_-adipocyte; cluster of differentiation 36 (CD36); mictoglia; $\beta$-amyloid peptide; ion channel; photoaffinity labeling

\section{1. 金岡研究室で学んだこと：「生物有機化学が} めざすもの」

1967 年に卒業研究生として, 北海道大学薬学部 の金岡祐一先生が主宰する薬品合成化学講座（以 下，金岡研）に配属になり，研究生活がスタートし た。金岡研は薬学部への昇格に伴って前年度に開設 された新しい研究室であり，金岡教授，米光 宰助 教授以下，若々しい町田 實，谷澤和隆の両助手， 佐藤英助教務職員を擁して, 新興の意気に燃えてい た. 研究分野は, 先生が NIH 留学で体得してこら れた今でいう「生物有機化学」であり, 生命現象を 化学の力で解き明かそうという, 新研究室にふさわ しいものであった。学部学生にとって生物有機化学

熊本大学大学院 - 医学薬学研究部 (T862-0973 熊本市 大江本町 5-1)

e-mail: jin@gpo.kumamoto-u.ac.jp

本総説は, 平成 19 年度退職にあたり在職中の業績を中 心に記述されたものである.
の何たるかを十分に理解できる力はなかつたが, 後 年, 先生が日本薬学会賞の受賞講演で示された「分 子の成り立ちと学問領域のヒエラルキー」の図を纬 見し，なるほど，そういうことなのかと得心した (Fig. 1).1）「三つ子の魂百まで」ではないが，研究 の出発点で受けたこの洗礼は, 定年を迎えた今振り 返ってみても私の研究の通奏低音として鳴り響いて いたことを強く感じる.

大学院修士課程での研究テーマとして与えられた のは「Meerwein 試薬を用いた酵素タンパクの化学 修飾」であった。強力なアルキル化剂としてもつぱ ら有機溶媒中での反応に用いられていた $\mathrm{Et}_{3} \mathrm{O}^{+}$ $\mathrm{BF}_{4}$ ，いわゆる Meerwein 試薬（MR）を水溶液での 反応に利用しょうとのアイデアは，今でこそ奇異で はなくなっているが，当時は大変ユニークなもので あった。この課題には既に研究室の浜田博士 $/$ 米光 先生が, 水溶液中におけるアミノ酸, ペプチドとの 反応性について調べておられた。私のテーマは「こ 


\begin{tabular}{|c|c|c|}
\hline レベル & 物質的単位 & 科学領域 \\
\hline 生物個体 & 哺乳類(ヒト) & 医学および臨床科学 \\
\hline $\begin{array}{l}\text { 組織集合 } \\
\text { (器官) }\end{array}$ & 単離した心臓、筋肉など & $\begin{array}{l}\text { 生理学、組織学、細胞学、 } \\
\text { 病理学、免疫学など }\end{array}$ \\
\hline 細胞集合体 & 組織 & \\
\hline 細胞 & 核、オルガネラ、ミトコンドリアなど & $\begin{array}{c}\text { 生化学、遺伝学、 } \\
\text { 微牛物学 }\end{array}$ \\
\hline サブ細胞レベル & 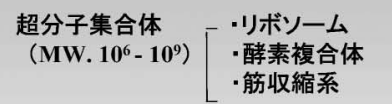 & <生体熾能化学> \\
\hline 多分子 & $\begin{array}{l}\text { 高分子 } \\
\left(M W .10^{3}-10^{6}\right)\end{array}\left[\begin{array}{l}\text {-タンパク質 } \\
\text { ·核酸 } \\
\text { ·複合糖質 }\end{array}\right.$ & \\
\hline 分子 & 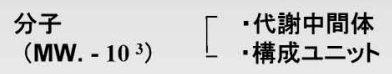 & 有機化学 \\
\hline 原子 & 原子 & 物理学、物理化学 \\
\hline サブ原子レベル & 電子、中性子など & 素粒子物理学 \\
\hline
\end{tabular}

Fig. 1. The Hierarchy of Molecular Organization and Related Sciences (Modified after Ref. 1)

れを酵素タンパクに応用す, 特に, 試薬がカチオン 性を持つことを利用して，トリプシン（カチオン性 アミノ酸を基質とする）の基質認識部位を構成する アミノ酸残基を同定する」ものであった，研究は，

自らの手で合成した人工基質や合成阻害剂を用いて トリプシン研究を展開しておられた谷澤先生に手ほ ぞきを受け，合成された競合阻害剂の 1 つである $\beta$-naphthamidine ( $\beta$-NA) を使わせて頂きながら進 めた。この研究結果をまとめて BBRC に報告した 内容 (私の最初の論文) ${ }^{2)}$ の概略を示した（Fig. 2). $0.2 \mathrm{M}$ の MR を用いた場合，修飾されるカルボキシ ル基の数は $\beta$-NA の有無によって 0.7 個（約 1 個） の差があり，このとき特異的な合成基質 BAEE (Bz-L-Arg-OEt) の分解活性にも正味 50\%の差が認 められた。したがって，トリプシンの基質特異性を 決めるのは確かにカルボキシル基（のちにこれは Asp-177 と同定された）であることを化学修飾法 (いわゆる, “Differential labeling”と呼ばれる方法) で示すことができた.

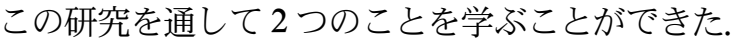
1 つは，水溶液中における「化学反応の質的な差」 である.すなわち，化学修飾の対象となる水溶液中 のトリプシン濃度はせいぜい $10^{-4} \mathrm{M}$ のオーダーで あるのに対して，水の濃度は $55 \mathrm{M}$ である。 それで も化学修飾が可能となるためには，トリプシン中の
カルボキシル基の求核性は水のそれよりも，少なく とも $55 / 1 \times 10^{-4}=55 \times 10^{4}$ だけ高くなければなら ぬ. なるほど，これが反応性の差，すなわち，反応 の “quality”というものかと納得した.

2 つ目は, 「科学研究における先取権とフェア精 神」である. この研究を進めているとき, 稲上 正 教授（Vanderbilt 大）が試薬こそ違え，同じような 研究をやっておられることが分かった，負けじと頑 張つたが，小差で先を越され，その結果はJBCに 掲載されてしまった。非常に残念だったが，その後 の日本生化学会で双方の報告が相次いで発表される ことになり，固唾を飲んだが，稲上先生はきちんと われわれの結果も引用された。われわれの BBRC でも，もちろんこの JBC を引用した．研究ではい くつかの研究が同時進行することはその後も経験し たが, 研究の出発点でこのようにフェアな姿勢に遭 遇できたのは大変よい勉強になった.

またこれをきっかけに，タンパク質の化学修飾に

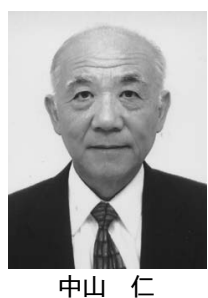

1942 年生. 北海道出身. 1968 年, 北大 薬学部卒. 1970 年, 大学院 (修士課程) を修了し北大薬学部・教務職員. 1979 年, カルフォルニア工科大へ留学. 助 手, 助教授を経て, 1993 年より熊本大 学薬学部教授. 2005-7 年, 同大学附属 図書館長を併任. 2008 年, 定年退職, 同大学名誉教授. 


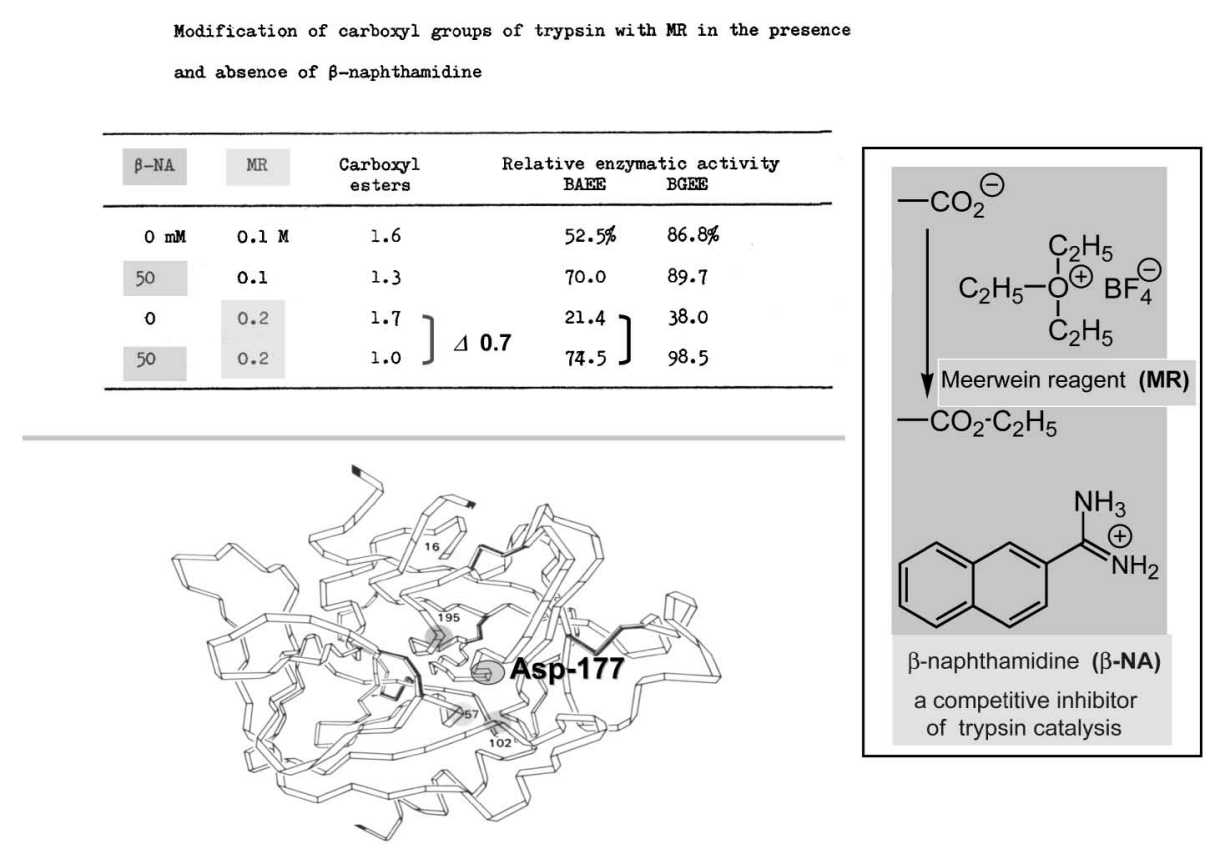

Fig. 2. Modification of Carboxyl Groups of Trypsin by Meerwein Reagent (From Ref. 2)

ついてじっくりと調べる機会を得た。図書室に閉じ こもって文献を調へ，反応試薬と反応条件，修飾夕 ンパク質とアミノ酸残基に分けて整理したカードを 作成した。これらをまとめて，金岡先生と共著で 「蛋白質・核酸・酵素」に総説を書かせていただい た. ${ }^{3)}$ また, 隣の生化学教室（石井信一教授主宰） の輪読会にも参加していた経緯から, Means \& Feeney 本の翻訳 ${ }^{4)} に も$ 加えて頂き，カルボキシル基 の修飾の部分を担当した．また少しあとで学会出版 センターから刊行された「タンパク質の化学修飾 （上・下）」（大野，金岡，崎山，前田・共著）では, 光アフィニティラベリングの部分を担当させて頂い た. ${ }^{5)} こ の$ 部分は主に Knowles 教授の Methods in Enzymology の 1 章を参考にしながら執筆したもの だが，このときに学んだこと，及び畑中保丸博士 (現・富山大・薬・教授）を中心に研究室で進めら れていた有機光化学反応に関する見聞は，あとに同 博士の協力の下, 光アフィニティラベリング法を受 容体やイオンチャネルの研究に展開していく上で大 きな礎となった。

また，金岡研ではもう 1 つの柱として，町田博士 を中心に生体内のチオール基（SH 基）と反応した ときだけ蛍光を発するというユニークなマレイミド 型蛍光試薬の開発が展開されていたが，ここで見聞 した蛍光化合物の取り扱いと測定法，測定結果の解

\section{研究の概要}

I. 酵素タンパクの化学修飾 (1968-1976)

II. 受容体、イオンチャネルの構造と機能（1977 -1992）

III. 熊本大学薬学部での研究 (1993 - 2008)
(1) CD36 との遭遇
(2) 脂肪細胞の新しい機能
(3) ミクログリア·サブタイプの異なった機能と アルツハイマ一病治療応用への可能性

Fig. 3. Brief Chronology of My Resarch (1968-2008)

析法（蛍光極大波長とミクロ環境の極性との関係, 2 つの蛍光基間のエネルギー移動と距離の関係）な どの内容はその後の学位をまとめる上で大いに役立 った．昔から芸は身を助けるというが，何がごこで 身を助けることになるか分からないと今改めて思う.

その後の研究も含め, 私の研究概要を Fig. 3 に まとめた。

2. 受容体, イオンチャネル研究へ

学位取得後, 光アフィニティラベリングを受容体 研究に活かしたいとの思いから，カリフォルニア工 科大学 (Caltech) の M. Raftery 教授の下に留学す る機会を得た。この留学決定にはちょっとしたエピ 
ソードがある，前述の MR の結果を BBRC に報告 した同じ頃，たまたま，同教授も同じ試薬をリゾ チームの触媒中心にあるカルボキシル基の修飾に適 用した論文を Biochemistry に発表されたのを知つ ていたので, applicationの手紙にその旨書いたの がすんなりと OKして頂いた一因の由. 37 歳の遅 い留学であったが，それなりに期するところはあっ た。当時, Raftery 教授はニコチン性アセチルコリ ン受容体（nAchR）のタンパク質化学の研究では パスツール研の Changeux 教授と世界を二分する勢 いで，数多くの論文を発表され，少なくないグラン 卜を獲得しておられた。しかしテーマを決める際, 私は敢えて同研究室ではいまだマイナーであった $\mathrm{Na}^{+}$チャネルの研究を選んだ。その理由は, nAchR のタンパク質化学的研究は既にピークを越 しており， $\mathrm{Na}^{+}$チャネル研究のこれからに賭けて みたいという直感からであった。

ご存知のように受容体やイオンチャネルの含量は 少ないので，1970 年代後半にタンパク質化学的な 研究を行うには（今日の遺伝子工学的技術を活用す るにはいまだ至っていなかった，しかるべき生物 材料を必要とした。nAchR の場合はシビレエイの 発電器官が, $\mathrm{Na}^{+}$チャネルには電気ウナギの発電 器官がそれぞれ用いられた。テーマは，それまで部 分精製に留まっていた「電気ウナギ発電器官の
$\mathrm{Na}^{+}$チャネルを単離する」ことに決まった。幸い, 大学院生の 1 人がこの分子に対するモノクローナル 抗体（Mab）の作製に成功したので，この抗体を immunoaffinity purification に活用してチャネル分 子の精製を行った (Fig. 4)。可溶化・部分精製し た $\mathrm{Na}^{+}$チャネルと Mabの混合物を, Protein ASepharose (A) と DEAE-Sephadex（B）のカラム を用いて 2 段階精製すると， $\mathrm{Na}_{+}$チャネルと $\mathrm{Mab}$ の $1: 1$ 複合体が得られた（C)。テトロドトキシン （TTX）結合の比活性（3000 pmol/mg protein）で 評価したこの標品の純度は $75 \%$ に達しており， $\mathrm{Mab}$ 部分を除けばほぼ純粋な $\mathrm{Na}^{+}$チャネルが得ら れたことになる. ${ }^{6}$

帰国後，発表されたばかりのこの論文を読まれた 故・沼 正作教授（京都大・医）から電話がかかつ てきて, $\mathrm{Na}^{+}$チャネルの全一次構造を決める共同 研究をやろうとの提案を受けた。われわれが受け持 つたタンパクの部分一次配列を決めるためには，前 述の精製標品（Mab も混在）よりもさらに精製度 を上げる必要があった。 S-S 結合を切って変性させ たのちに Sepharose 4B カラムにかけて, SDSPAGE 上でも均一な $\mathrm{Na}^{+}$チャネルタンパクを得た [Fig. 5(A) ]。これを松尾壽之先生（当時，宮崎医 大）の研究室に持参し，寒川，南野両博士の協力を 得て，トリプシン消化物を HPLC で分離し，その

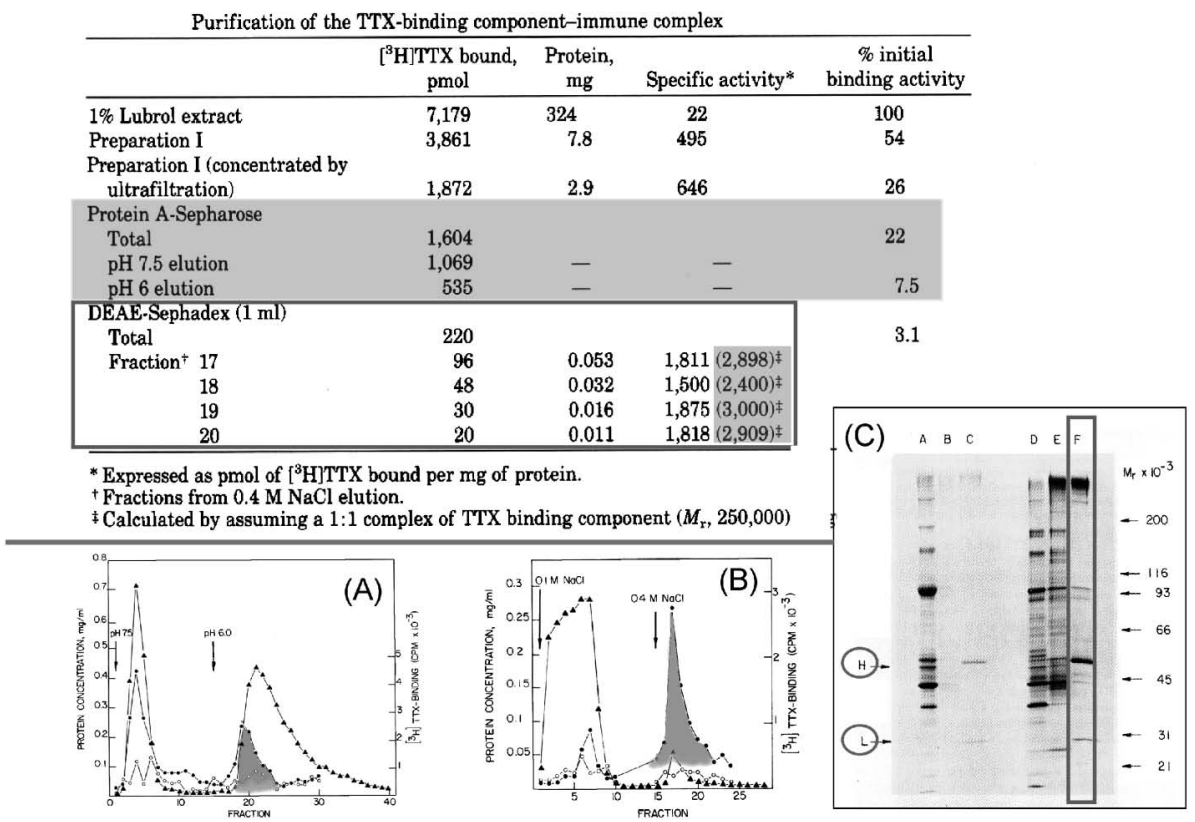

Fig. 4. Immunoaffinity Purification of Sodium Channel from Electric Eels by Its Monoclonal Antibody (From Ref. 6) 

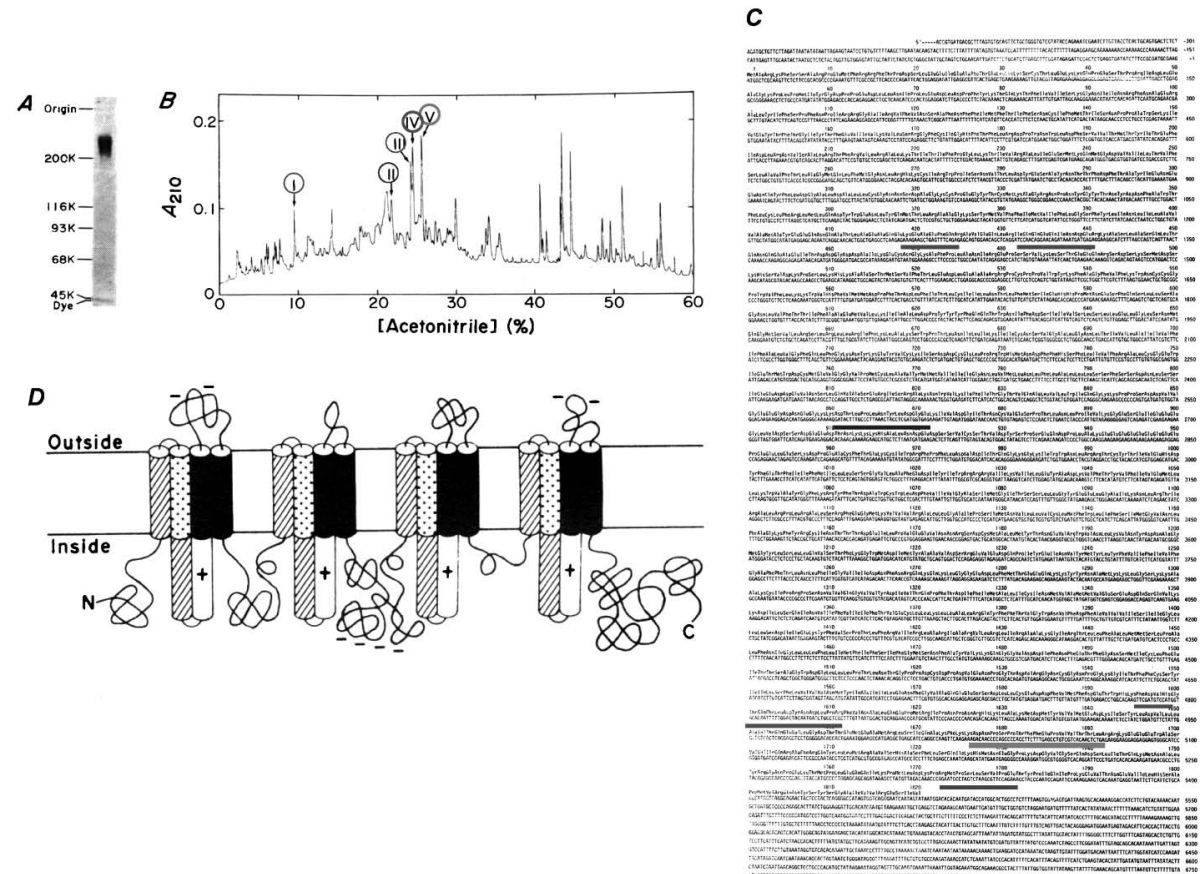

Fig. 5. Determination of Total Primary Structure of Sodium Channel from Electric Eels by Partial Amino Acid Sequence of the Protein followed by cDNA cloning (From Ref. 7)

A: SDS-PAGE of a highly purified sodium channel protein. B: a HPLC profile of peptide fragments of the channel protein after trypsin digestion. Five fractions (I-V) were subjected to the $\mathrm{N}$-terminus sequencing to reveal the sequence of totally six peptide fragments, because the fraction I contained two peptide fragments. C: Nucletide sequence of the cDNA that encodes the sodium channel protein. All the six peptide sequences were included within the total primary sequence. D: The initial membrane topology model proposed in the paper (Ref. 7)).

中の 5 つのペプチドピーク [Fig. 5(B)］を最新鋭 の $N$ 末端配列分析計にかけてペプチド断片の一次 配列を読み取った。当時，この $\mathrm{ABI}$ の最新鋭機は 日本に 3 台しかなく，そのうち 2 台を松尾研で持つ ておられた。この部分配列の情報を基に，沼研では 野田助教授（現・基生研・教授）を中心に cDNA の配列解析が急ピッチで進み，1830 残基（当時最 長）の一本鎖からなる電気ウナギ発電器官由来の $\mathrm{Na}^{+}$チャネル分子の全一次構造は共同研究開始か ら 1 年あまりという短期間で決定した [Fig. 5(C) ]. 7) この論文が出たのち，アメリカの 2 つのグループが 同じ課題に取り組んでいたことを聞いた。総勢 17 名がスクラムを組んだ日本チームに女神は微笑んで くれた.

この成果は，その後に続く $\mathrm{Ca}^{2+}$ チャネルや $\mathrm{K}^{+}$ チャネルなど一連の電位依存性イオンチャネル構造 の嚆矢として，また構造生物学のみならず，チャネ ル機能との関連から電気生理学や薬理学分野にも大 きなインパクトを与えた。例えば，電位依存性を決 める構造実体として，特徵ある S4 セグメント [Fig. 5(D) では+で示されている] がどのイオンチ
ヤネルにも共通に存在するなどの事実である。た だ，最初に提案された膜卜ポロジーモデル [Fig. 5 (D) ] では，このS4 が細胞質側におかれていた. これはチャネルが開くとき, 電気生理学的には細胞 膜の内側から外側に向かって流れるゲート電流が観 察されるのだが，それを担う構造部を S4 で説明し ようと強く意識したためである，なお，その後のモ デルでは，この S4（及び S3）は他のセグメント同 様に膜の中にあると訂正された。

チャネル分子の膜トポロジーを明らかにする方法 として，その部位のペプチド配列を認識する抗ペプ チド抗体を用いて免疫組織学的にこれを証明する方 法がある。われわれは，野々村禎昭先生（東大 ・ 医，現・微化研・理事長）が自ら試料調製と電顕観 察をされるという特段のご協力を得て，チャネルの $\mathrm{C}$ 末端は細胞質側にあり，この部分の配置は上記の モデルと合致することを明らかにした。 ${ }^{8,9)}$

もう 1 つの例として, $\mathrm{Na}^{+}$チャネルの薬理学か らも重要なフグ毒・テトロドトキシン（TTX）の 結合部位について少しだけふれたい。TTXを細胞 膜の外側から加えても特異的に $\mathrm{Na}^{+}$チャネルだけ 
をブロックすることから，その結合部位はチャネル 分子の細胞膜外側にあると考えられてきた。われわ れは光アフィニティラベル法によってこれを検証す ベく取り組んだが，TTX 誘導体合成の収率の低さ や光反応基の選択, ${ }^{10,11)}$ 光ラベルされたペプチドの 同定法などで困難を極めた。しかし畑中博士の協力 もあって，沼らによる点変異実験の結果 ${ }^{12)}$ と相前後 して，ドメイン III とIVの細胞外ループにラベル部位 を同定できた（Fig. 6). ${ }^{13)}$ 日本では縄文時代からフ グを食してきたが，明治になってフグ毒の本体は TTX であることが田原良順先生によって明らかに された。また楢橋敏夫教授による $\mathrm{Na}^{+}$チャネル特 異的ブロッカーとしての TTX の薬理学的確立に加 え，その複雑な化学構造は津田恭介先生，平田義正 先生，Woodward 教授の 3 グループによって 1964 年の IUPAC で同時に発表されるなど，TTX と日 本人研究者のつながりは深いが， $\mathrm{Na}^{+}$チャネル上 の TTX 結合部位もまた日本人研究者の手でなし遂 げられたのである。

さて, $\mathrm{Na}^{+}$チャネルについで $\mathrm{L}$ 型 $\mathrm{Ca}^{2+}$ チャネ ルの全一次構造も沼研から発表された。このチャネ ルは循環器疾患の効果的な治療薬である $\mathrm{Ca}$ 拮抗薬 の標的分子である．薬学に身を置く者として，この 結合部位を明らかにすることに取り組んだ。まず最
初に，最も代表的な $\mathrm{Ca}$ 拮抗薬であるジヒドロピリ ジン（DHP）類から始めた。Na チャネルで苦労し た経験を活かし，光反応基も 1,1,1-trifluoromethyl phenydiazirine など適切なものを選択し，同定法も 予想されるチャネルの特定部分のいくつかに対して あらかじめぺプチド抗体を作製しておき，その反応 性で判定した。その結果，研究はスムーズに進展し た。チャネル分子と DHP 型試薬は 1：1 で結合し ているにも係らず，得られたラベル部位はドメイン III とIVの 2 力所であり，そのどちらもが S5-S6 セ グメントにまたがる部分であった $[\mathrm{Fig} .7(\mathrm{~A})] .{ }^{14)}$ 一見不思議なこの結果は，Fig. 7 (B) で示すよう に，平面構造では離れているこれらの部位が立体構 造上では近接して存在すると考えるとよく説明でき ることが初めて分かった．実際，解析が進んでいる $\mathrm{Ca}^{2+}$ チャネルの立体構造研究でも，これを支持す

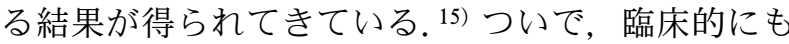
優れた日本発の $\mathrm{Ca}$ 拮抗薬 diltiazem（ベンゾチアゼ ピン型）の結合部位はドメインIVの S5-S6 セグメ ントであり, ${ }^{16,17)}$ また新規の開発を目指した semotiadil ではドメインIVの S6 セグメントのみである ことも明らかにした. ${ }^{18)}$

欧米のグループが明らかにしたフェニルアルキル アミン型薬物を除いた 3 つの薬物の結合部位をわれ

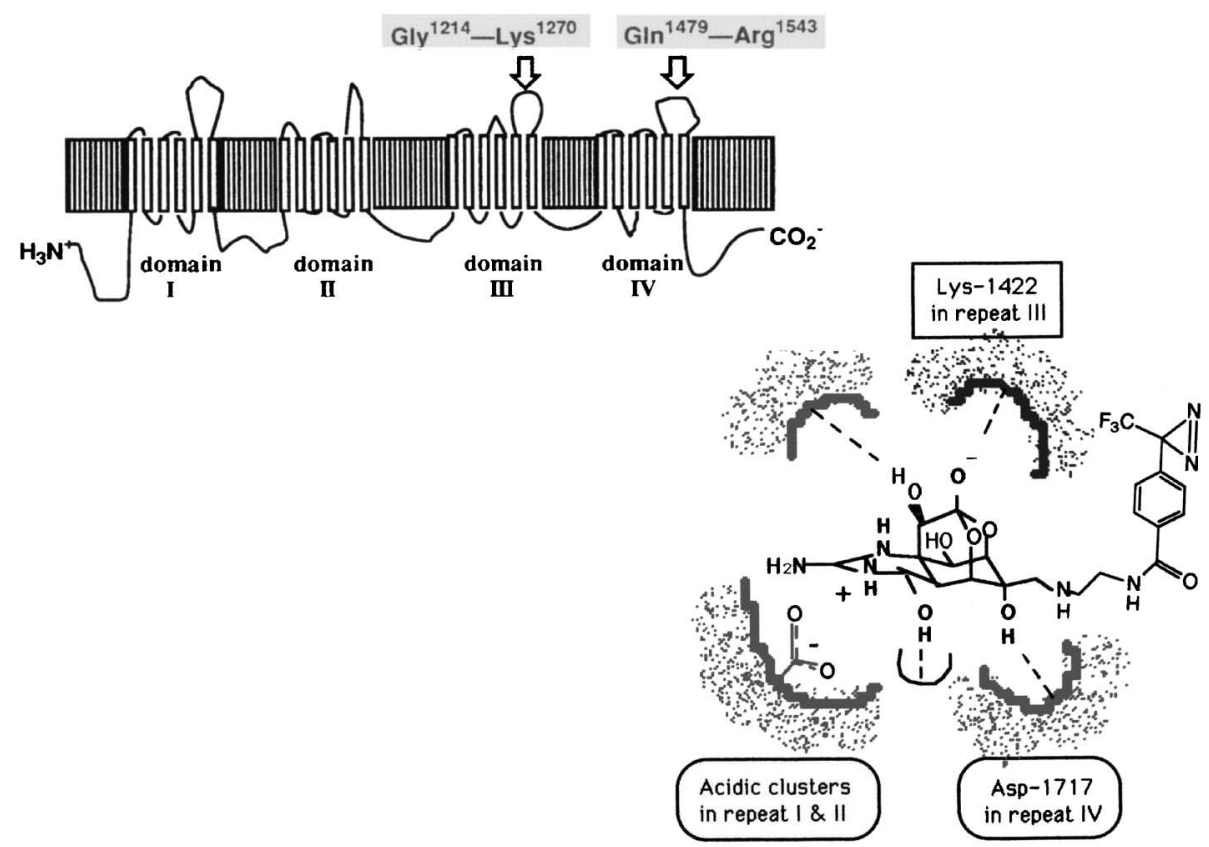

Fig. 6. TTX Binding Sites within Sodium Channel

A: Two regions of connection loop between S5 and S6 in the domain III and IV were identified by photoaffinity labeling method. B: A model of TTX binding sites of the photosensitive TTX derivative depicted by the results of photoaffinity labeling study (Ref. 10,11) and site-directed mutagenesis by Terlau et al. (Ref. 12) 

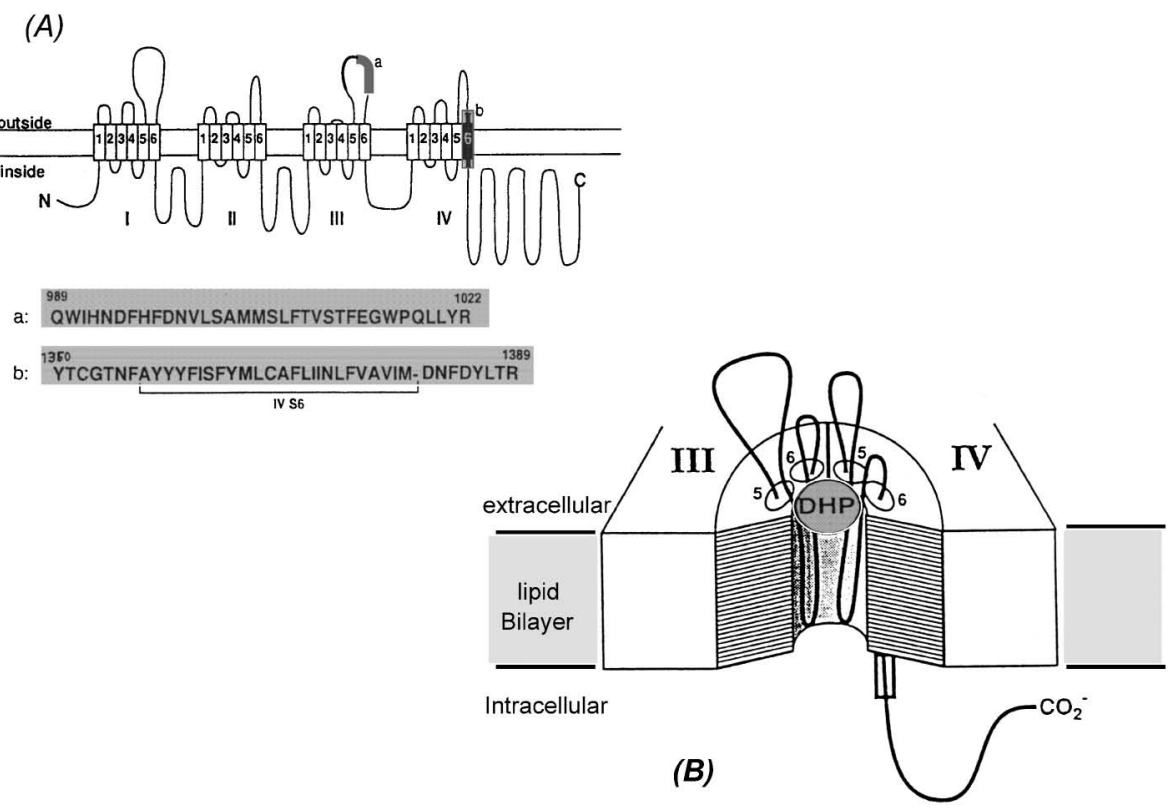

Fig. 7. DHP Binding Sites Identified by Photoaffinity Labeling within L-type Calcium Channel (From Ref. 14)

われは明らかにしたが，それらをまとめてみると， 細胞膜の外側，内側という違いはあるが，いずれも $\mathrm{Ca}^{2+}$ チャネルのドメイン III あるいはIV の S5 セグ メントやS6 セグメントに集中しているのが分かる (Fig. 8)。これらの結果は薬理学的知見をうまく説 明できるものであり，リガンド結合部位を明らかに する上で光アフィニティラベル法が有用であること を改めて示すことができた．特に「DHP 結合部位 が細胞膜外側のチャネル透過孔近傍である」という 成果は, 当時の薬理学研究では明確な答えが出てい ない内容であった。そのため，班員として加えて頂 いた「心電活動」の重点領域では，総括班長の平 則夫先生（東北大・医）から大変お誉め頂いた。

ここで，光ラベル部位同定法の改良について一言 だけふれておきたい。上述のように，これまではそ のツールとして標的タンパクの部分配列を持つ合成 ペプチド（群）に対する抗体（抗ペプチド抗体）を あらかじめ用意しておき，それらと光ラベル化され たタンパク質のプロテアーゼ消化断片との反応性の 有無によってラベル部位を絞り込んでいく方法が主 流であった。しかしこれでは手間が掛かり過ぎるだ けではなく, ぞのアミノ酸残基に光ラベルされたか まではほとんどつきとめられない。これを克服する 手段として，光ラベル化断片を HPLC 又は抗リガ ンド抗体で濃縮したのち，それを最新の質量分析法 （TOF-MS 及び ESI-MS/MS）を活用することによ

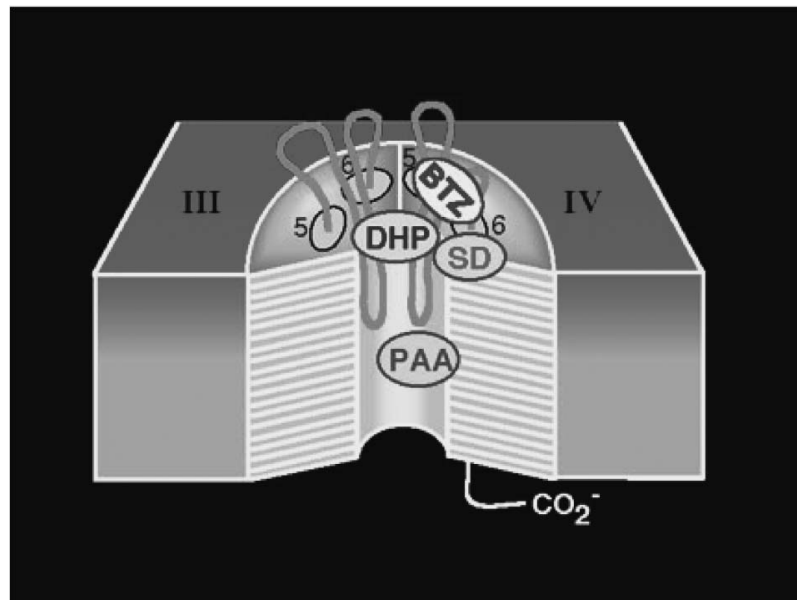

Fig. 8. Schematic Model of Binding Sites of Typical Calcium Antagonists within L-type Calcium Channel, Which were Identified by Photoaffinity Labeling

DHP: dihydropyridines, BTZ: benzothiazepines, PAA: phenylalkylamines, and SD: semotiadil.

って一挙に一次構造中のラベルアミノ酸残基まで同 定する方法を，サントリー生有研の石黒正路部長, 益田勝吉博士との密なる共同研究によって示すこと に成功した. ${ }^{19,20)}$

3. CD36 分子との遭遇：思いがけないきっかけ もある

これまで，光アフィニティラベル法の利用とし て，タンパク質分子中のリガンド（あるいは薬物） 結合部位を同定するという，高い分解能を要するも 
のについて述べてきた．光ラベル法のより一般的な 用い方は，多成分からなる生物試料の中から標的分 子（タンパク質のみならず，核酸や糖質，脂質など の場合もあろう）に目印を付け，その同定に役立て ることであろう.

われわれも，共同研究として心筋の ATP 感受性 $\mathrm{K}^{+}$チャネルを同定すべく，そのサブユニットであ るスルホニルウレア受容体（SUR）を釣り上げて くることをもくろんだ. ラベル用リガンドとしてス ルホニルウレアの 1 つである glibenclamide (GB) を用い，ブタ心筋の sarcolemma 画分の光ラベル化 を行った. $80 \mathrm{kDa}$ のラベル化タンパク質を均一に まで精製し， $\mathrm{N}$ 末端配列分析を行い 39 残基まで同 定することができた。 ところが得られたこの配列 は，期待していた SUR ではなく，CD36（血小板， 乳腺由来）あるいは脂肪酸トランスポートタンパク 質（脂肪組織由来）と呼ばれる分子であった。後に クローニングされた心筋の SUR は GB に対する親 和性が弱い（ $\mu \mathrm{M}$ オーダー）ことから，われわれの 実験では親和性の高い CD36が釣り上がってきたと 解釈された

さて，CD36 はマクロファージ（M $\phi)$ ではクラ ス B に属するスカベンジャー受容体として, 脂質 代謝や糖代謝において重要な役割を果たしているこ
とが分かりつつあつたそそこでわれわれは，この分 野の研究を精力的に進めておられた熊本大・医の堀 内正公教授，宮崎 章講師 (現・昭和大・医・教授) に協力をお願いした。 大学院生の大神信孝君（現・ 中部大・講師）が頑張って実験し，M $\phi$ の CD36 は 糖化タンパクの後期生成物（advanced glycationend products；AGE）を取込夕分解する受容体とな つていることを明らかにした。. ${ }^{21)}$ さらに同じクラス B スカベンジャ一受容体に属する SR-B1 は，高密 度リポタンパク（HDL）中のコレステロールエス テル（CE）の選択的な引き抜き活性と，細胞内の 遊離コレステロール（FC）をアポリポタンパク A 1 へ放出する活性を併せ持つが，AGE が共存すると この活性が著しく阻害されることを見い出した (Fig. 9). ${ }^{22)}$ すなわち，CD36をはじめとするスカ ベンジャー受容体の働きが糖尿病や動脈硬化の進展 と深く係わっていることを明らかにした。

一方，教室の國安明彦准教授は脂肪細胞の CD36 に注目し，大胆な発想をした。 $\mathrm{M} \phi$ の CD36 が酸化 低密度リポタンパク（Ox-LDL）を取り込み，分解 する活性を持つのであれば，脂肪細胞の CD36 も同 じ活性を示しても不思議はないと考えた。これが見

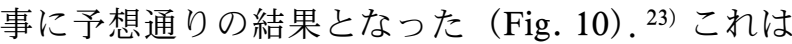
一見何でもないことに思われるが，従来，脂肪細胞

(a) Selective uptake of HDL-CE

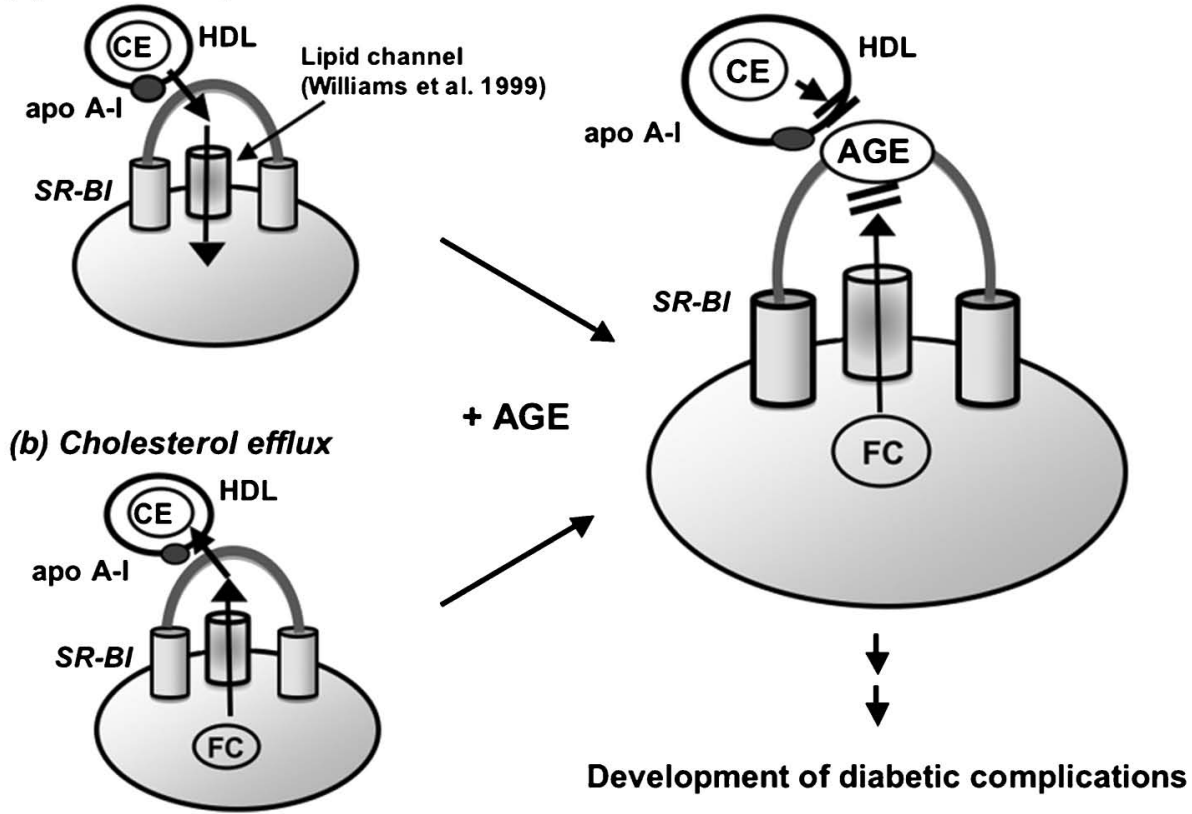

Fig. 9. AGE-BSA Inhibits SR-BI-mediated Bi-directional Cholesterol Flux in Macrophage (From Ref. 22) 
A

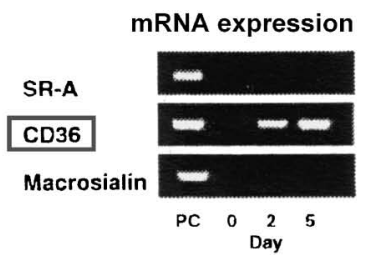

Cellular uptake of Ox-LDL

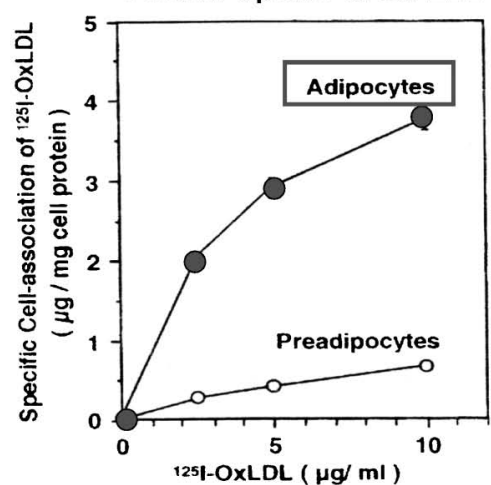

B

CD36 protein expression

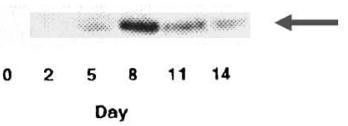

Fig. 10. Matured Adipocytes Phagocytose Ox-LDL Mediated by CD36 (From Ref. 23)

の CD36 は長鎖脂肪酸の取り込み分子（fatty acid transporter；FAT）として機能して分子であり，取 り込まれた長鎖脂肪酸はグルコーストランスポー ター（GLUT4）を介して別途取り込まれたグルコー スと反応して，蓄積エネルギ一源としてのトリグリ セリド（TG）生成に使われるとの考え方，すなわ ち,「CD36 は脂肪細胞ではもつぱら生体内エネル ギー蓄積細胞としての機能を担うだけである」とす る考えに修正を求めた点に大きな意義がある．ここ で見い出された新たな機能によって，スカベンジ ヤー機能で処理できない量の酸化 LDL (Ox-LDL) が存在する状態（動脈硬化前期）では，脂肪細胞も また病態進展にスイッチを入れてしまう訳で，この 知見は病態生理学的にも示唆に富んでいる. 彼のグ ループは AGE もまた, 脂肪細胞の CD36 で取り込 まれることも見い出し, ${ }^{24)}$ 糖尿病の進行が動脈硬化 発症と関連することも報告した。ささらにこの研究を 推し進め, 脂肪細胞 CD36 が Ox-LDL を取り込ん だのちのイヴェントとして, resistin や PAI-1 など のアディポサイトカイン類の産生・放出レベルが大 きく変動していることも見い出している. ${ }^{25,26)}$ メ夕 ボリックシンドロームにおける脂肪細胞と $\mathrm{M} \phi$ の 相互作用がホットなトピックになっている現在，さ らなる研究の展開が待たれるところである.
4. ミクログリアの CD36 : アルツハイマー病研 究へのアプローチ

誤解を恐れずにいえば，ミクログリア $(\mathrm{mG})$ は 中枢における $\mathrm{M} \phi$ といえよう。末梢における CD36 の機能は，上述のように $\mathrm{M} \phi$ や脂肪細胞でみてき たが，mGではどんな機能を担っているだろうか？

$\mathrm{mG}$ の研究を始めるに当たって，その中枢におけ る役割がどのようにとらえられてきたかを調べてみ た。そのほとんどが，外因的あるいは内因的を問わ ず中枢になんらかの異変が起きたときに $\mathrm{mG}$ は動 員され，活性化された mG は TNF $\alpha$ や IL-1, IL-6 及び NO などの，いわゆる炎症性サイトカイン類 やメディエーターを放出して，この異変を力づくで 排除する，という考え方であった。しかし当時， $\mathrm{mG}$ にもこのような神経傷害的な作用だけではな く，神経保護的な働きもあるとの見解も出始めてい た（例えば，高坂らの総説27)を参照)。一方で，澤 田 誠教授（現・名大・環境医学研）らは, $\mathrm{mG} の$ 1 型，2 型と呼ぶ細胞株を樹立し，これらに発現す る細胞マーカーや神経細胞との共培養実験から，1 型が神経傷害的な従来型の $\mathrm{mG}$ で， 2 型が神経保護 的な $\mathrm{mG}$ ではないかと提唱していた。この $\mathrm{mG} の 2$ つのサブタイプの機能に関するわれわれのさらなる 展開については後述することにする.

われわれの $\mathrm{mG}$ 研究は，高坂新一博士（国立神 経セ・所長）が p53 欠損マウスから樹立された細 
胞株 MG5 を恵与頂き，これを用いて炎症刺激に対 する細胞応答を調べることからスタートした。この 研究では熊本大・医の森 正敬先生（現・名誉教 授，崇城大・薬・教授）と後藤知己講師，親泊政一 博士（現・徳島大・ゲノム機能セ・教授）のご指導 を頂き，大学院生の川原浩一君（現・熊本大・薬 · 助教）が力を発揮してくれた。 LPS/IFN $\gamma$ による炎 症刺激を加えると，MG5 細胞には核の断片化や caspase 3 の放出など典型的なアポトーシスが惹起

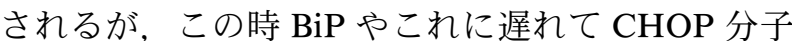
の発現が認められた。すなわち，小胞体ストレス （ER ストレス）機構によるアポトーシスであるこ とをきれいに示すことができた（Fig. 11）. ${ }^{28)}$ MG5 細胞には p53 が欠損していることからその関与を 考えずに明快な結論を導くことができた。なお， 森，親泊らは糖尿病をはじめとする種々の疾患にも この ER ストレスが深く関与することを明らかにし たが，mG においても同様の機構が働くことを示し た点でも意義深い.

さて，われわれは $\mathrm{mG}$ のサブタイプ 1,2 型では 機能に違いがあると考えていることを前述したが, その内容をin vitro とin vivo の実験を通して得た 3 つの結果を紹介したい。 In vitro 実験系では，ラッ 卜新生仔脳由来の mixed glial culture を澤田らの方 法で分離した 1 型及び 2 型 $\mathrm{mG}$ の初代培養細胞を 用いた。一方，in vivo 実験系はラット又はマウス の脳内に被験物質を微量注入して調べた。

第 1 の成果は， 2 型には反応せず， 1 型 $\mathrm{mG}$ との み反応するモノクローナル抗体 KM9F5 を開発した ことである。抗原としての $\mathrm{mG}$ の調製は，上記の 澤田らの方法を用いた。 Figure 12 に示す通り，抗
Iba1 抗体が mG 全般を染めるのに対し，KM9F5 は $\mathrm{mG}$ の一部（1 型）としか反応しない。また， KM9F5 は M $\phi$ と全く反応しない点でも抗 Iba1 抗 体とは異なっており， 1 型 $\mathrm{mG}$ に特異性の高い抗体 であることが分かる (特許出願中).

第 2 の成果は，LPS/IFN $\phi$ 処理したときの 1 型 と 2 型の応答の違いである. 培養 $\mathrm{mG}$ を用いた in vitro の系では，炎症性の TNF $\alpha$ 及び iNOS の発現 レベルは 1 型が圧倒的に高いのに対し， 2 型ではわ ずかであった。この結果が in vivoにも反映されて いるか否かを, adult rat 脳の一方に LPS/IFN $\phi$ を 微量注入して調べた。この解析でも，上述した抗 Iba1 抗体とわれわれが開発した KM9F5 との併用が 効果を発揮した。すなわち，iNOS の産生は約 1 日 で最大となるが，産生のほとんどが 1 型 $\mathrm{mG}$ に限 られていることが確認できた（Fig. 13）.

第 3 の成果は，アルツハイマー病（AD）の発症 原因の 1 つとみなされているオリゴマー状の $\beta$ ア ミロイドペプチド（o-A $\beta$ ) が，活性化ミクログリ アによってクリアランスという興味深い知見である.

M $\phi$ に発現する CD36 などのスカベンジャー受容体 （SR）が Ox-LDL や AGE を食食することは前述し たが，川原浩一君と「mGにも $\mathrm{SR}$ が発現している のであれば $\mathrm{mG}$ が $\mathrm{A} \beta$ を領食するはずで， $\mathrm{mG}$ の神 経保護的な作用は 2 型 $\mathrm{mG}$ によるものではないか」 という仮説を立て，調べてもらったところ，「本当 に o-A $\beta$ を取り込みますよ。しかも IL-4 で刺激し た 2 型の方が活性はずっと強いです!」という嬉し い結果が得られた。さらに領食・分解活性を担う分 子群も分かってきた. ${ }^{29)}$ 次のステップは，このユ ニークな o-A $\beta$ のクリアランス機構が in vivo でも
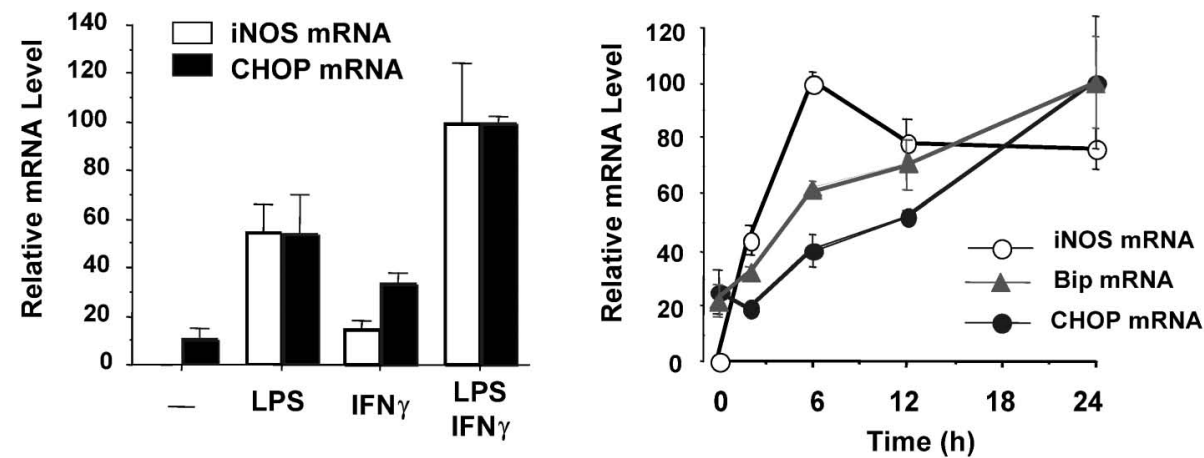

Fig. 11. LPS/IFN $\gamma$-induced Apoptosis in MG5 Microglia Was Involved in Enhanced Expression of mRNA for iNOS and CHOP (From Ref. 24) 


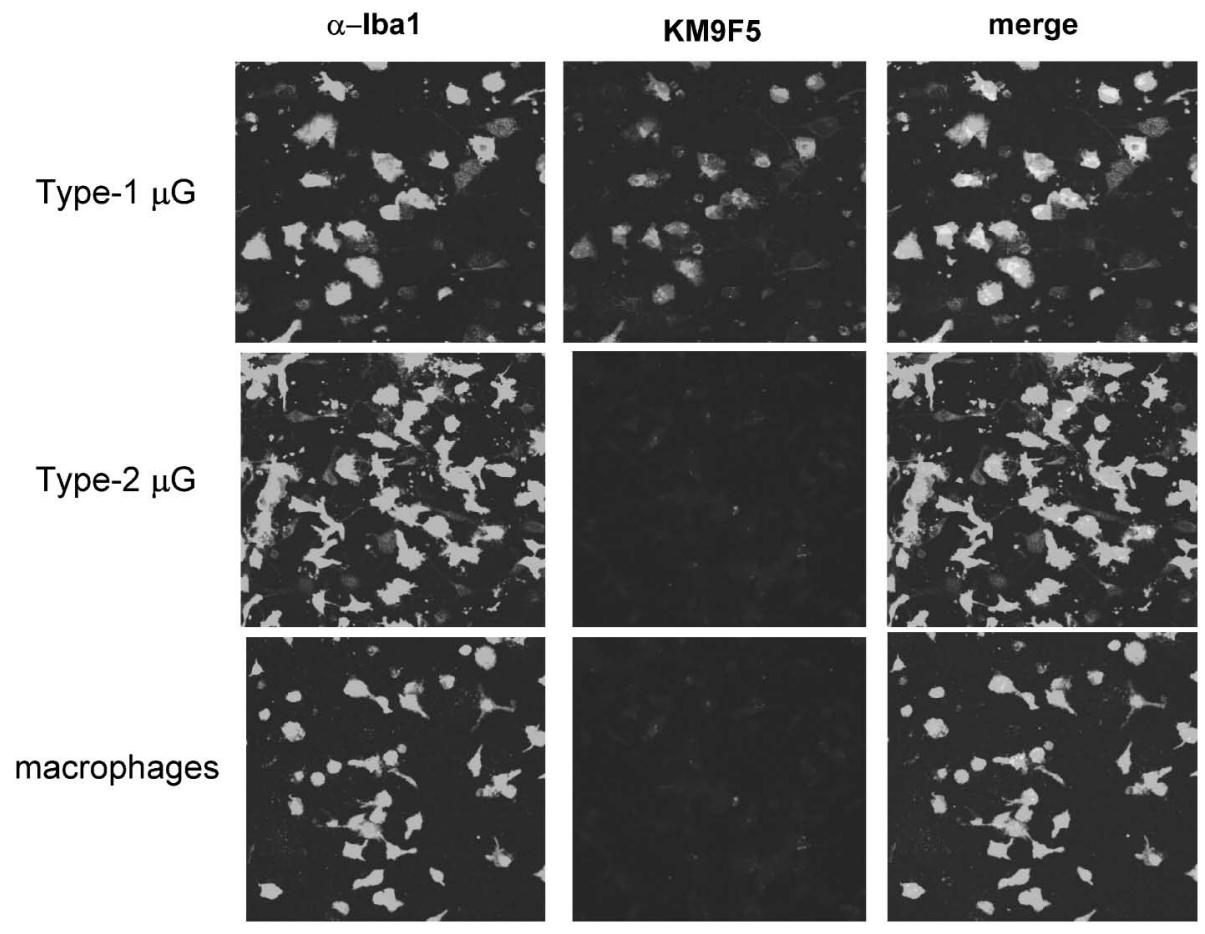

Fig. 12. Development of a Unique Monoclomal Antibody That Selectively Recognizes Type-1 Microglia

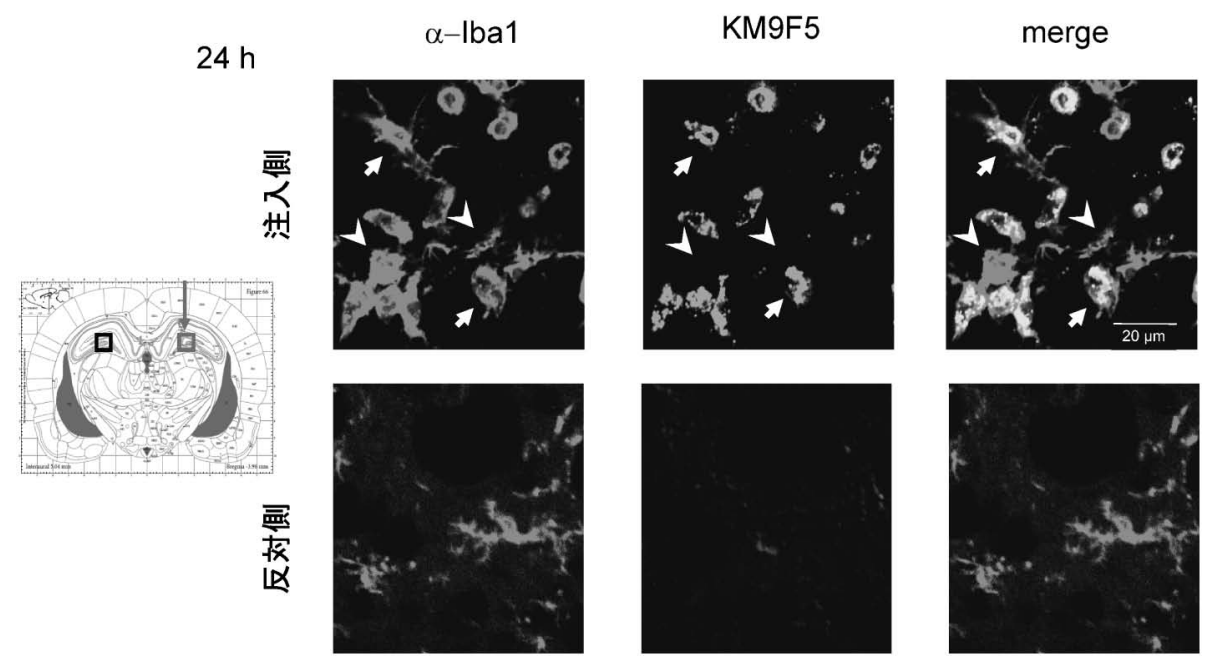

Fig. 13. LPS/IFN $\gamma$ Selectively Activates Type-1 Microglia at the Ipsi-lateral Side of Adult Rat Brain

起こることを示さねばならない. $\mathrm{AD}$ モデル動物 は，比較的早期に A $\beta$ の蓄積が始まる APP23 マウ スがよいとの情報を得て，その開発者 M. Staufenbiel 博士（Novartis Pharma, Basel）に恵与頂いた. In vivo では IL-4 に加えて IL-13 も合わせて脳の一 方側に微量注入し，その効果をモリス水迷路及び脳 切片の抗 $\mathrm{A} \beta$ 抗体による染色度の減少で評価した。 マウスの供与を受ける際，統計的に意味のあるデー
タとするには $n>15$ としなければと言われていた ので，それだけ手間ヒマがかかる実験であった。幸 い，多くの大学院生諸君が項張ってくれたおかげ で，意味のあるデータが得られている（投稿準備 中). この成果を今後新しい $\mathrm{AD}$ 治療法へと結び付 けるためには，この $\mathrm{mG}$ によるクリアランス能を 誘導できる低分子化合物を探す必要がある，われわ れの仕事に興味を持って下さる先生方のご協力を得 
て，現在このような化合物がみつかりつつある。こ の段階で私は定年を迎え時間切れとなったが，川原 君をはじめ若い諸君らも頑張ってくれている．さら なる進展を楽しみにしたい。

謝辞研究の出発点から今日まで，「研究とは 何ぞや」を教えて頂いた恩師・金岡祐一名誉教授に 深く感謝いたします．筆者の研究は多くの方々との 共同研究の集成であり，本文中に引用できなかった 次の方々に記して深く感謝の意を表します：前田 浩名誉教授, 崎山文夫名誉教授，小田切優樹教授, 赤池孝章教授，A. Schwartz 教授，W. A. Catterall 教授，H. Glossmann 教授，J. Striessnig 教授，内 藤一秋博士，矢花秀雄博士，芝野俊郎博士，平岡昌 和名誉教授，川野誠子准教授，大泉 康名誉教授， 大倉正道准教授, 瀬山一正名誉教授, 山岡 薰教 授, 木下英司准教授, 高濱和夫教授, 白崎哲哉准教 授，竹屋元裕教授，村田和義博士，永井竜児博士， 澤田 誠教授，玉巻伸章教授，野原稔弘名誉教授， 今村順茂准教授，故・後藤正文教授。また，赴任し た熊本大学薬学部において協力を惜しまれなかった 中山守雄助教授（現・長崎大・教授）と原田久美子 博士に深く感謝したい。北海道大学・薬学部（薬品 合成化学講座, 生体機能化学講座) 及び熊本大学・ 薬学部 (放射薬品学研究室, 生体機能化学研究室), 熊本大学大学院 - 医学薬学研究部 (細胞機能分子解 析学分野）の研究室に在籍され, 研究に尽力頂いた 多くの方々に改めてお礼申し上げる．最後に，執筆 の機会を与えて頂いた本誌編集委員長・宮田直樹教 授に感謝します。

\section{REFERENCES}

1) Kanaoka Y., Yakugaku Zasshi, 100, 973-993 (1980).

2) Nakayama H., Tanizawa K., Kanaoka K., Biochem. Biophys. Res. Commun., 40, 537541 (1970).

3) Kanaoka Y., Nakayama H., Tanpakushitsu Kakusan Koso (Protein Nucleic Acid Enzyme), 16, 403-410 (1971).

4) Ishii S. (translated in Japanese by Ishii S., Kasai K., Nakayama H., Nakata H.), " 'Chemical Modification of Proteins: Principles and Applications," eds. by Means G. E., Feeney
R. E., Hirokawa-Shoten, Tokyo (1973).

5) Nakayama H., Kanaoka Y., Chap. 4, "Photoaffinity Labeling," in "Chemical Modification of Proteins (2)" eds. by Ohno M., Kanaoka Y., Sakiyama F., Maeda H., Gakkai-Shuppan Center, Tokyo (1981).

6) Nakayama H., Withy R. M., Raftery M. A., Proc. Natl. Acad. Sci. U.S.A., 79, 7575-7578 (1982).

7) Noda M., Shimizu S., Tanabe T., Takai T., Kayano T., Ikeda T., Takahashi H., Nakayama H., Kanaoka Y., Minamino N., Kangawa K., Matsuo H., Raftery M.A., Hirose T., Inayama S., Hayashida H., Miyata T., Numa S., Nature, 312, 121-127 (1984).

8) Nakayama H., Nakayama K., Nonomura Y., Kangawa K., Matsuo H., Kanaoka Y., Pept. Chem., 1987, 795-797 (1988).

9) Nakayama H., Nakayama K., Nonomura Y., Kobayashi M., Kangawa K., Matsuo H., Kanaoka Y., Biochim. Biophys. Acta, 1145, 134-140 (1993).

10) Nakayama H., Yoshida E., Kanaoka Y., Chem. Pharm. Bull., 34, 2684-2689 (1986).

11) Yoshida E., Nakayama H., Hatanaka Y., Kanaoka Y., Chem. Pharm. Bull., 38, 982987 (1990).

12) Terlau H., Heinemann S. H., Stuehmer W., Putsch M., Conti F., Imoto K., Numa S., FEBS Lett., 293, 93-96 (1991).

13) Nakayama H., Hatanaka Y., Yoshida E., Oka K., Takanohashi M., Amano Y., Kanaoka Y., Biochem. Biophys. Res. Commun., 184, 900907 (1992).

14) Nakayama H., Taki M., Striessnig J., Glossmann H., Catterall W.A., Kanaoka Y., Proc. Natl. Acad. Sci. U.S.A., 79, 7575-7578 (1982).

15) Murata K., Odahara N., Kuniyasu A., Sato Y., Nakayama H., Nagayama K., Biochem. Biophys. Res. Commun., 282, 284-291 (2001).

16) Watanabe T., Kalasz H., Yabana H., Kuniyasu A., Naito K., Nakayama H., Schwartz A., Vaghy P. L., FEBS Lett., 334, 261-264 (1993).

17) Motoike H. K., Bodi I., Nakayama H., Schwartz A., Varadi G., J. Biol. Chem., 274, 9404-9420 (1999). 
18) Kuniyasu A., Itagaki K., Shibano T., Iino M., Kraft G., Schwartz A., Nakayama H., J. Biol. Chem., 273, 4635-4641 (1998).

19) Kawahara K., Kuniyasu A., Masuda K., Ishiguro M., Nakayama H., Biochem. J., 363, 223-232 (2002).

20) Masuda K., Kawahara K., Kuniyasu A., Ishiguro M., Nakayama H., Mass Spectrom., 53, 18-24 (2005).

21) Ohgami N., Nagai R., Ikemoto M., Arai H., Kuniyasu A., Horiuchi S., Nakayama H., $J$. Biol. Chem., 276, 3195-3203 (2001).

22) Ohgami N., Nagai R., Miyazaki A., Ikemoto M., Arai H., Horiuchi S., Nakayama H., J. Biol. Chem., 276, 13348-13355 (2001).

23) Kuniyasu A., Hayashi S., Nakayama H., Biochem. Biophys. Res. Commun., 295, 319323 (2002).

24) Kuniyasu A., Ohgami N., Hayashi S., Miya- zaki A., Horiuchi S., Nakayama H., FEBS Lett., 537, 85-90 (2003)

25) Tokunaga M., Master's dissertation (Kumamoto University) (2007).

26) Kuniyasu A., Tokunaga M., Yamamoto T., Shudo T., Kai H., Nakayama H. (in preparation).

27) Nakajima K., Kohsaka S., "Response of Microglia in Brain injury,'” in Neuroglia, 2nd ed., eds. by Kettenmann H., Ransom R.S., Oxford University Press, Oxford, 2005, pp. 443-453.

28) Kawahara K., Oyadomari S., Gotoh T., Nakayama H., Mori M., FEBS Lett., 506, 135-139 (2001).

28) Shimizu E., Kawahara K., Kajizono M., Sawada M., Nakayama H., J. Immunol. (in press) 